\title{
EFFECT OF METHANOL CONCENTRATION AS A SOLVENT ON TOTAL PHENOLIC AND FLAVONOID CONTENT OF BELUNTAS LEAF EXTRACT (Pulchea indica L.)
}

\author{
N. P. Sinta Mahasuari ${ }^{1}$, N. L. P. Vidya Paramita ${ }^{1 *}$, A. A. G. R. Yadnya Putra ${ }^{1}$ \\ ${ }^{1}$ Department of Pharmacy, Faculty of Mathematics and Natural Science, University of \\ Udayana, Jimbaran, Badung, Bali, Indonesia
}

Corresponding author email: vidya_paramita@unud.ac.id

\begin{abstract}
Background: Beluntas (Pluchea indica L.) is an Indonesian plant that grows wild and is used as traditional medicine. Beluntas leaves are reported to contain phenolic, and flavonoid is a part of phenolic compounds. Phenolic compounds other than flavonoids include 1,3,4,5-tetra-Ocaffeoylquinic acid, 3,4,5-tri-O-caffeoylquinic acid, chlorogenic acid, and ferulic acid. Flavonoid compounds in beluntas leaves are quercetin, apigenin, luteolin and chrysoeriol. Methanol solvents are reported to be able to extract higher polyphenol and flavonoid contents than other solvents. Objective: The purpose of this study is to determine the effect of $20 \%$, $50 \%$ and $75 \%$ solvent concentration of methanol on total phenol and total flavonoid levels of beluntas leaf extract. Methods: In this study, the extraction process was carried out by maceration, the determination of total phenol content was carried out by the Follin-Ciocalteu method. Determination of total flavonoid levels was carried out by the Colorimetric method. Data on phenol and flavonoid levels were analyzed statistically. Results: The yield of beluntas leaf extract in this study was respectively from the lowest methanol concentration of $24.094 \%$ $\mathrm{w} / \mathrm{w}, 31.126 \% \mathrm{w} / \mathrm{w}, 24.838 \% \mathrm{w} / \mathrm{w}$. The value of total phenol levels increased with increasing methanol concentration, namely $124.84 \mathrm{mg} \mathrm{GAE} / \mathrm{g}, 138.3 \mathrm{mg} \mathrm{GAE} / \mathrm{g}$, and $147.91 \mathrm{mg} \mathrm{GAE} / \mathrm{g}$. The highest total flavonoid value in $75 \%$ methanol extract is $69.72 \mathrm{mg} \mathrm{QE} / \mathrm{g}$, followed by $20 \%$ methanol extract at $46.29 \mathrm{mg} \mathrm{QE} / \mathrm{g}$ and the lowest is found in $50 \%$ methanol extract at 32.80 $\mathrm{mg}$ QE/g. The results of statistical analysis using the Kruskal-Wallis test showed that there were significant differences $(p<0.05)$ in the value of total phenol levels and total flavonoids of the three extracts. Conclusion: The difference in the concentration of methanol solvents affects the value of total phenol levels and total flavonoids with the highest value produced by a $75 \%$ methanol solvent.
\end{abstract}

Keywords: Beluntas Leaves (Pluchea indica L.), Total Phenol Content, Total Flavonoid Content, Gallic Acid, Quercetin.

\section{INTRODUCTION}

Indonesia is a country rich in biodiversity. Some plants are made as alternative drugs for treating diseases. One of Indonesia's native plants is widely spread and potentially to develop namely the beluntas plant (Pluchea indica L.) of the family Asteraceae ${ }^{[1]}$. Beluntas leaves are often used as a traditional medicine to eliminate body

odour, increase appetite, joint pain, back pain, glandular tuberculosis, rheumatism ${ }^{[2]}$, reduce fever, overcome vaginal discharge, overcome irregular menstruation ${ }^{[3]}$, overcome diarrhea, and help digestion ${ }^{[4]}$.

The compounds contained in beluntas leaves are tannins, sterols, flavonoids, and phenol hydroquinone ${ }^{[5]}$. One of the phenol 
compounds present on the beluntas leaves and is the identity compound of beluntas leaves, namely quercetin ${ }^{[6]}$. Quercetin is categorized as flavonols, one of six subclasses of flavonoid compounds, which has biological activities Flavonoids are polar compounds, so they will dissolve in other polar solvents such as ethanol, methanol, butanol, acetone, dimethylformamide and others. Quercetin compounds in beluntas leaves have good solubility in solvent mixtures that have polarity over water because they are in the form of glycosides ${ }^{[7]}$.

Based on previous research ${ }^{[8,9]}$, the greatest total phenol and total flavonoid levels in beluntas leaves are by using methanol as a solvent. The use of a combination of solvent types in one mixture allows more polyphenol compounds to dissolve. The effect of using methanol-water composition gives different levels of acquisition because water is a polar compound that has a high polarity index and dielectric constant so that the mixture of water with solvents has a higher polarity than pure solvents ${ }^{[10]}$.

This study the determination of levels of phenols and flavonoids with variations in the concentration of methanol solvents. Research on total phenol and flavonoid levels in the extract of beluntas leaf obtained from methanol solvents with various variations of methanol solvents had never been done. So research is needed to see the effect of different concentrations of extraction solvents, namely methanol $20 \%, 50 \%$, and $75 \%$ on the total levels of phenols and total flavonoid levels from the leaves of beluntas Pulchea indica (L.). Determination of total phenol content can be expressed in $\mathrm{mg}$ of Gallic acid equivalent /g of sample and total flavonoid content expressed in $\mathrm{mg}$ of Quercetin equivalent/g of the sample ${ }^{[11,12]}$.

\section{METHODS}

\section{Instrument and Materials}

Beluntas leaves (Pluchea indica L.) obtained from the Manoko Balitro Gardens, West Bandung Regency, West Java, Methanol p.a $\left(\right.$ Merck $\left.^{\circledR}\right), \quad$ Aquadest $\left(\right.$ Bratachem $\left.^{\circledR}\right), \quad$ Gallic acid $\quad\left(\right.$ Sigma $\left.^{\circledR}\right)$, Quercetin $\quad\left(\right.$ Merck $\left.^{\circledR}\right), \quad$ Folin-Ciocalteu $\left(\mathrm{Sigma}^{\circledR}\right), \mathrm{AlCl}_{3}\left(\mathrm{Merck}^{\circledR}\right)$, rotary evaporator, $\mathrm{UV}-\mathrm{Vis}$ spectrophotometer

\section{Extraction}

Add 100 grams of dried beluntas leaf powder to the macerator with $1000 \mathrm{ml}$ of $20 \%$ $\mathrm{v} / \mathrm{v}$ methanol solvent added (1:10). Making extract using $50 \%$ and $75 \%$ concentration methanol solvents uses the same comparison that is $1: 10$. Maceration was performed for 3 days, with stirring twice a day, every 10 times stirring. The macerate was filtered with filter paper and concentrated with a vacuum rotary evaporator at $40^{\circ} \mathrm{C}$ until a viscous oven at $40^{\circ} \mathrm{C}$ until got a constant weight and determined the extract yield by the formula in equation 1.

$$
\% \text { Yield }=\frac{\text { extract } \text { weights }}{\text { sample } \text { weights }} \times 100 \%
$$

\section{Phytochemical Screening of Flavonoids and Phenols}

Phytochemical screening was carried out on each extract to determine the presence of flavonoid and phenol compounds. The test solution was prepared by dissolving 0.5 -gram thick extract with $10 \mathrm{~mL}$ methanol. The screening test method was adapted from the Indonesian Ministry of Health.

\section{Determination of Phenol Levels}

Phenol content testing refers to the procedure Chun et al (2003); Depkes RI et al. (2008); Malik et al. (2015) with some modifications. The total test phenol of beluntas leaf extract was carried out by the Folin-Ciocalteu method with gallic acid standard (GAE). Making a gallic acid calibration curve with the concentration used $3 ; 4,5 ; \quad 6 ; \quad 7.5 ; 9 ; 10.5 ; 12 \mu \mathrm{g} / \mathrm{mL}$. Measurement of total phenol levels was carried out by weighing $10 \mathrm{mg}$ of methanol extract $20 \%, 50 \%$ and $75 \%$, then dissolved to $10 \mathrm{~mL}$ with methanol p.a., so get the concentration of $1000 \mu \mathrm{g} / \mathrm{ml}$. Sample with a concentration of $1000 \mu \mathrm{g} / \mathrm{ml}$ was diluted until 
getting $50 \mu \mathrm{g} / \mathrm{ml}$ extract solution. Then, take $3 \mathrm{~mL}$ extract solution of $50 \mu \mathrm{g} / \mathrm{ml}$ concentration and added $0.4 \mathrm{~mL}$ of the FolinCiocalteu LP reagent. Next, added $4 \mathrm{~mL}$ of $1 \% \mathrm{NaOH}$ solution and $4.6 \mathrm{~mL}$ aqua dest, shake till homogeneous, incubated for 2 hours at room temperature. Absorption is measured at a maximum absorption wavelength of 730 $\mathrm{nm}$. Preparation of the sample solution was repeated six times. The phenol levels were obtained as mg GAE/g dried sample.

\section{Determination of Flavonoid Levels}

Determination of total flavonoid levels which refers to Chang et al. (2002); Ahmad et al. (2014) with some modifications. Determination of total flavonoid levels by a colorimetric method with quercetin standard (QE). Quercetin calibration curve was made by concentration of $0.5 ; 1,5 ; 2.5 ; 3.5 ; 4,5 ; 5.5$ $\mu \mathrm{g} / \mathrm{mL}$. Methanol extracts of $20 \%, 50 \%$, and $75 \%$ were weighed $10 \mathrm{mg}$ each and dissolved in $10 \mathrm{~mL}$ methanol p.a. Add $1 \mathrm{~mL}$ of extract solution with $3 \mathrm{~mL}$ of methanol, $0.2 \mathrm{~mL}$ of $10 \% \mathrm{AlCl}_{3}, 0.2 \mathrm{~mL}$ of sodium acetate $1 \mathrm{M}$ and aqua dest until $10 \mathrm{~mL}$. After that, incubated for 30 minutes at room temperature. Absorption is measured at a wavelength of $415 \mathrm{~nm}$. The sample solution was made in 6 replications. Flavonoid levels were obtained as $\mathrm{mg} \mathrm{QE} / \mathrm{g}$ of dried samples.

\section{Data Analysis}

The statistical data is the result of total phenol, and flavonoid levels from each methanol extract beluntas (Pluche indica L.) leave. The statistical method used is KruskalWallis if there is a significant difference in the Kruskal Wallis Test $(p<0.05)$ then the test is continued with the Mann-Whitney test. Statistical analysis using the SPSS 22 application for Windows.

\section{RESULTS AND DISCUSSION}

The extraction process of beluntas leaves (Pluchea indica) by maceration method. Maceration is a simplicia extraction process that uses certain solvents with several stirring at room temperature ${ }^{[19]}$. Remaceration is a process of repeating the addition of solvents after previous macerate filtering ${ }^{[20]}$. The purpose of re-maceration was to filter the compounds that are still left behind or are not founded. Regular stirring is also carried out to homogenize the compound to contact with the liquid solution to get the maximum extraction results. The extracts yield is a comparison between the extract weight obtained with the simplicia weight ${ }^{[20]}$. The amount of yield from an extract indicates the amount of active ingredient that can be extracted based on the solvent and the method. The percentage of extract yield from the extraction obtained can be seen in Table 1.

The extract yield results in the table showed that the methanol extract $50 \%$ higher than methanol extract $20 \%$ and $75 \%$. This is because the extract component does not only consist of flavonoid compounds, but there are other compounds ${ }^{[21]}$. Based on the nature of polarity, water has a high polarity, so that it can attract polar compounds and methanol is a universal solvent that can attract polarly, semi-polar, and non-polar compounds. So that the yield of the extract at $50 \%$ is able to attract other compounds contained in the extract so that the yield obtained is high.

The high yield obtained is due to the main component extracted in the form of polyphenols which have polar and nonpolar groups. The yield of extract in this study is much higher than the yield of methanol extract yield reported by Safitri et al. (2018), which is $23 \% \mathrm{w} / \mathrm{w}$.

Table 1. The yield of Beluntas (Pluchea indica L.) Leaf Extract

\begin{tabular}{cccc}
\hline Sample & Powder Weight (gram) & Extract Weight (gram) & Yield (\%)b/b \\
\hline 20\% methanol extract & 100 & 24.094 & 24.094 \\
$50 \%$ methanol extract & 100 & 31.126 & 31.126 \\
$75 \%$ methanol extract & 100 & 24.838 & 24.838 \\
\hline
\end{tabular}


Table 2. Phytochemical Screening Results of Phenol and Flavonoids Beluntas (Pluchea indica L.) Leaf Extract

\begin{tabular}{|c|c|c|c|c|}
\hline Sample & $\begin{array}{l}\text { Phytochemical } \\
\text { Screening }\end{array}$ & References & The Results & Information \\
\hline $20 \%$ & \multirow[t]{3}{*}{ Flavonoid } & \multirow{3}{*}{$\begin{array}{c}\text { Intensive yellow } \\
\text { fluorescence solution, } \\
\text { showing the presence } \\
\text { of flavonoid (Depkes } \\
\text { RI, 1995) }\end{array}$} & $\begin{array}{l}\text { Yellow fluorescence on } \\
\text { UV light } 366 \mathrm{~nm}\end{array}$ & (+)flavonoid \\
\hline $50 \%$ & & & $\begin{array}{l}\text { Yellow fluorescence on } \\
\text { UV light } 366 \mathrm{~nm}\end{array}$ & (+)flavonoid \\
\hline $75 \%$ & & & $\begin{array}{l}\text { Yellow fluorescence on } \\
\text { UV light } 366 \mathrm{~nm}\end{array}$ & (+)flavonoid \\
\hline $20 \%$ & \multirow[t]{3}{*}{ Phenol } & \multirow{3}{*}{$\begin{array}{l}\text { The formation of } \\
\text { dark blue or blackish } \\
\text { green (Vijayalakshmi } \\
\text { dan Ravindhran, } \\
\text { 2012). }\end{array}$} & blackish green color & (+) Phenol \\
\hline $50 \%$ & & & blackish green color & (+) Phenol \\
\hline $75 \%$ & & & blackish green color & (+) Phenol \\
\hline
\end{tabular}

On the dissolved process using a mixture of organic-water solvents, it is said that the polar group will be dissolved in a polar water solvent ${ }^{[22]}$. While the compounds with nonpolar groups will be dissolved in organic solvents which have semi-polar then water.

Phytochemical screening is one of the methods used to determine active ingredients which are secondary metabolites in the sample ${ }^{[23]}$. Phytochemical screening results from each extract can be seen in table 2 . The result of phytochemical screening of phenols and flavonoids in this study showed that the sample of beluntas leaves methanol extract with a concentration of $20 \%, 50 \%$, and $75 \%$ contains phenol and flavonoid compounds. This is the same with the study of Widyawati et al. (2012), which showed that the methanol extract of beluntas leaves positively contained phenol and flavonoid compounds. Besides that, in Indonesian Herbal Formalurium (FHI) which showed that the identity compound of beluntas leaf is quercetin compound which is a flavonoid group ${ }^{[6]}$.

In determining phenol and flavonoid levels, first, make a standard calibration curve to get a linear regression equation to know the correlation between concentration and absorbance through spectroscopic measurements. The results of the calibration curve can be seen in Figures 1 and 2. The linear regression equation is shown in the figure. On the standard acid, gallic curve the value of the correlation coefficient $(r)$ is 0,9929. While, the standard curve of quercetin, the value of $r$ is 0,9974 . The value of $r$ close to 1 indicates a linear calibration curve, and there is a correlation between the concentration of the solution and absorption value $^{[25]}$.

The results of the determination of total phenol in beluntas leaf extract (Pluchea indica L.) at figure 3 , show that the value of total phenol increases with the increasing concentration of the methanol solvent. Methanol solvent $75 \%$ concentration was able to dissolved phenol with the highest levels of $147.91 \pm 1.13 \mathrm{mg} \mathrm{GAE} / \mathrm{g}$. The highest level of flavonoid in figure 4 in this study was the use of $75 \%$ methanol solvent in the amount of $69.72 \pm 0.15 \mathrm{mg} \mathrm{QE} / \mathrm{g}$. In previous study Safitri et al. (2018), stated that phenol content in the methanol extract of beluntas leaves was obtained at $84.11 \mathrm{mg}$ GAE/g sample while the flavonoid level was $51.59 \mathrm{mg} \mathrm{QE} / \mathrm{g}$ sample. Based on these result, phenol and flavonoid levels by using variations in the concentration of methanol solvent are greater than pure methanol solvent. Methanol solvent 75\% concentration can dissolve phenols and flavonoids better than solvents with lower concentrations. This is consistent with the statement of Salim et al. (2019), that methanol-water mixture which has more water composition than methanol will give lower levels of yield. This can be caused by the carbohydrate content in the extract will be dissolved in the water solvent, while the complex formation of some phenolic 


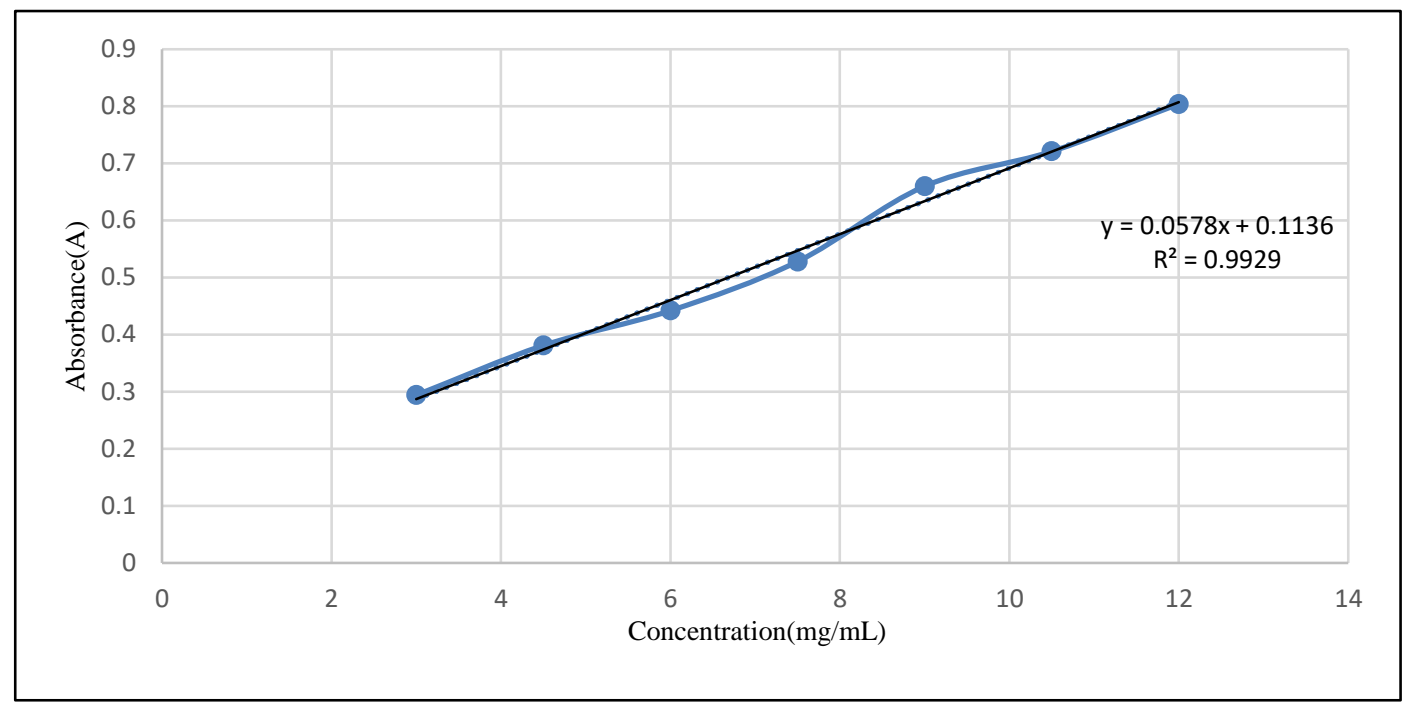

Figure 1. Standard curve for gallic acid

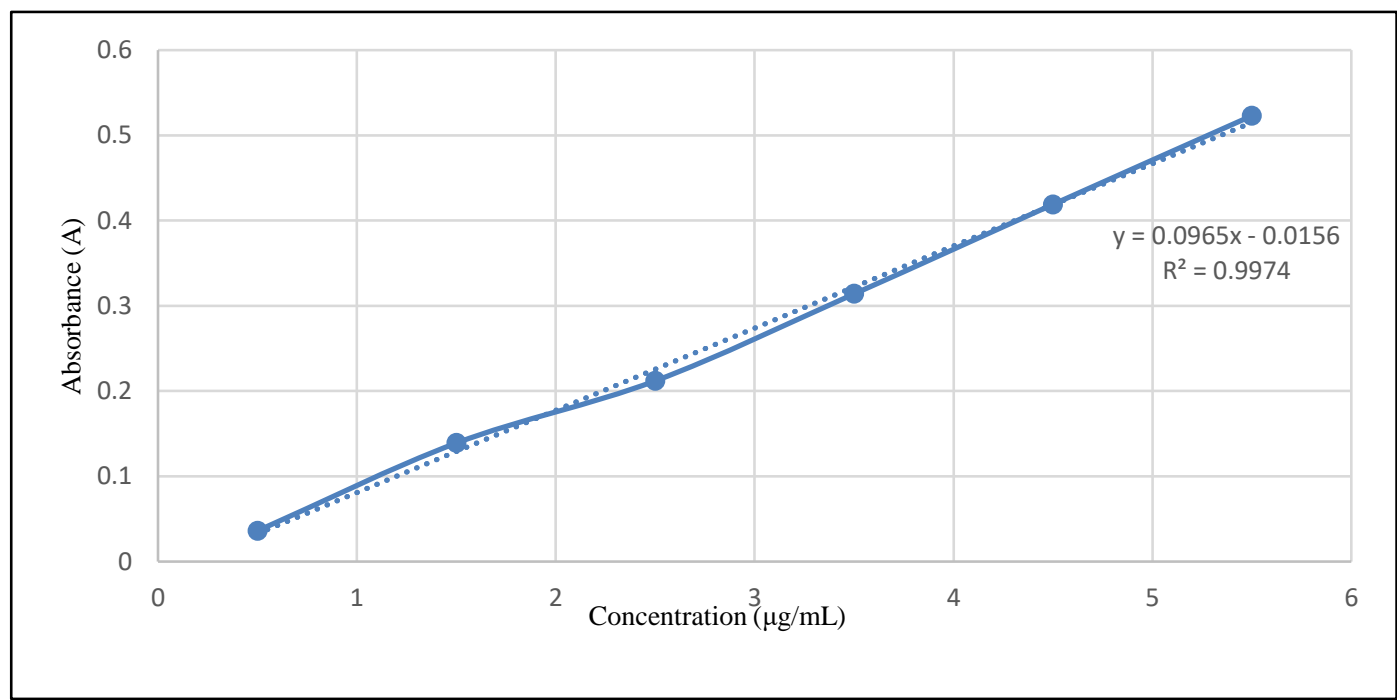

Figure 2. Quercetin standard curve

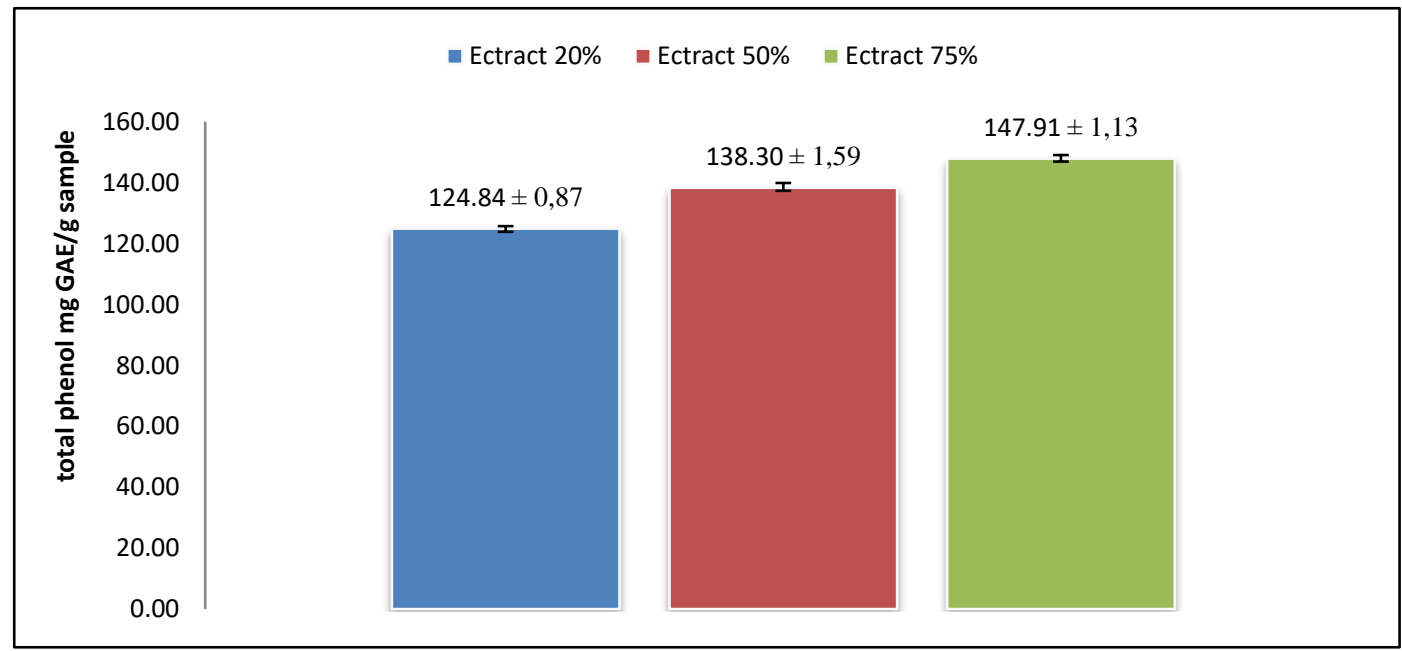

Figure 3. Graph of total phenol content extract of beluntas (Pluchea indica L.) leaf 


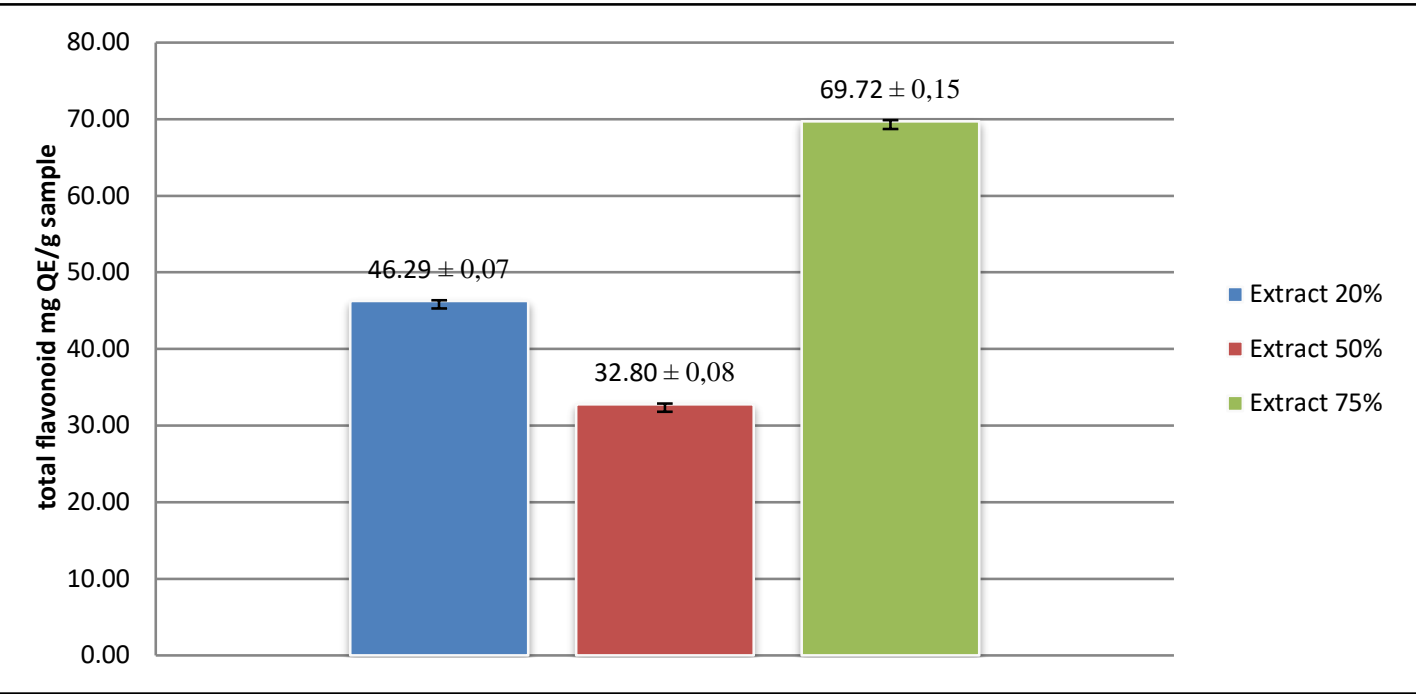

Figure 4. Graph of total flavonoid content extract of beluntas (Pluchea indica L.) leaf

compounds in the extract will dissolve in the methanol solvent. The combination of solvents in one mixture are allows more polyphenol compounds to dissolve $\mathrm{e}^{[10]}$. This is also caused by the higher levels of methanol used, the more phenols are dissolve.

The results of the phenol and flavonoid levels in this study were much higher than the results reported by Safitri et al (2018), that showed the phenol levels in the methanol extract of beluntas leaves were obtained at $84.11 \mathrm{mg} \mathrm{GAE} / \mathrm{g}$ sample, while the flavonoid levels obtained were $51.59 \mathrm{mg} \mathrm{QE} / \mathrm{g}$ sample. The effect of using methanol-water composition gives different levels of phenol and flavonoid because water is a polar compound that has a high polarity index and dielectric constant so that the mixture of water with a solvent has a higher polarity than pure solvents $^{[10]}$.

The highest total phenol and flavonoid is $75 \%$ methanol solvent was inversely proportional to the highest extract yield in $50 \%$ methanol solvent. This can be caused because the components of beluntas leaf extract not only consist of flavonoid compounds, but there are other compounds, whose solubility varies in solvents, including compounds that are soluble in water.

The results of statistical analysis using the Kruskal-Wallis non-parametric test showed that variations in the concentration of methanol had an effect on the total phenol and flavonoid total of each extract. The results showed a significant difference in the value of total phenol and total flavonoid with a significance value of $0,000(\mathrm{P}<0.005)$.

\section{CONCLUSION}

The highest yield in the methanol extract of beluntas leaves (Pluchea indica L.) in the $50 \%$ methanol extract with the yield of $31.126 \% \mathrm{w} / \mathrm{w}$. The increase in the concentration of methanol solvents affects of total phenol and flavonoid total, which is the highest results are obtained from $75 \%$ methanol solvent with a total phenol content of $147.91 \pm 1.13 \mathrm{mg} \mathrm{GAE} / \mathrm{g}$ of sample and the total flavonoid totals of $69.72 \pm 0,15 \mathrm{mg}$ $\mathrm{QE} / \mathrm{g}$ of sample.

\section{CONFLICTS OF INTEREST}

This paper was written independently. All authors do not disclose financial or personal relationships with others that can affect work.

\section{ACKNOWLEDGMENT}

We thank the lecturers and staff in the Department of Pharmacy, Faculty of Math and Science, Udayana University, Bali Indonesia, for their support in conducting this research. 


\section{REFERENCES}

1. Fitriansyah. M. I., dan Indradi. R. B. Review: Profil Fitokimia dan Aktivitas Farmakologi Baluntas (Pluchea indica L.), Farmaka 2018; 16(2):337-346.

2. BРОТКОМ. Panduan praktis pengobatan tradisional, UPTD Balai Pengembangan Obat Tradisional dan Kesehatan Olah Raga Masyarakat; 2017.

3. Kemenkes RI. Farmakope Herbal Indonesia, Edisi I Suplemen II, Kementrian Kesehatan Republik Indonesia, Jakarta; 2011.

4. Winarno, M. Wien dan D. Sundari. Pemanfaatan Tumbuhan Sebagai Obat Diare di Indonesia, Pusat Penelitian dan Pengembangan Farmasi Balai Penelitian dan Pengembangan Kesehatan Departemen Kesehatan Republik Indonesia, Jakarta; 1998.

5. Safitri. I., Nuria. M. C., dan Puspitasari. A. D. Perbandingan Kadar Flavonoid Dan Fenolik Total Ekstrak Metanol Daun Beluntas (Pluchea indica L.) Pada Berbagai Metode Ekstraksi, Inovasi Teknik Kimia 2018; 3(1):31-36.

6. Kemenkes RI. Farmakope herbal Indonesia, Edisi I Suplemen III, Kementrian Kesehatan Republik Indonesia, Jakarta; 2013.

7. Arifin, B., dan Ibrahim, S. Struktur Bioaktivitas dan Antioksidan Flavonoid, Jurnal Zarah 2018; 6(1): 21-29.

8. Widyawati, P. S., Budianta, T. D., Kusuma, F. A., Wijaya, E. L., Yuanatan, D. I., Wongso, R. S. Potency of beluntas (Pluchea indica Less) leaves extract as antioxidant and anti warmed over flavour (WOF) of duck meat, Faculty of Thecnology and Food Industry Slamet Riyadi University Surakarta, Proceeding of International Congress Challenges of Biotechnological Research in Food and Health, Wardana et al. Slamet Riyadi University, Surakarta; 2014

9. Wijaya, E. L., Wongso, R. S., Kusuma, F. A., Yuanatan, D. I., Widyawati, P. S., Budiantara, T. D. W. Identification Of Phytochemical Compounds In Polar
Extracts Of Belutas Leaf (Pluchea indica), Departement of Food Technology Soegijapranata Chatolic University Semarang, Global Insight for the Future of Food Production, Widya Mandala Chatolic University, Surabaya; 2013.

10. Yohed, I., dan Kristianita, R. A. Pengaruh Jenis Pelarut Dan Temperatur Terhdap Total Phenolic Content, Total Flavonoid Content, Dan Aktivitas Antioksidan Di Ekstrak Daun Nyamplung (Calophyllum inohyllum), Skripsi, Fakultas Teknologi Industri Institut Teknologi Sepuluh Nopember, Surabaya; 2017.

11. Senet, M. R. M., Raharja, I. G. M. A. P., Darma, I. K. T., Prastakarini, K. T., Dewi, N. M. A., Parwata, I. M. O. A. Penentuan Kandungan Total Flavonoid Dan Total Fenol Dari Akar Kersen (Mutigia calabura) Serta Aktivitasya Sebagai Antioksidan, Jurnal Kimia 2018; 12(1):13-18.

12. Setiokusumo. C., Widyawati. P. S., Budianta. T. D. W. Pengaruh Proporsi Daun Beluntas (Pluchea indica less) Dan Teh Hijau Terh.Adap Aktivitas Antioksidan Produk Minuman, Jurnal Teknologi Pangan dan Gizi 2016; 15(1):1-6.

13. Depkes RI. Materia Medika Indonesia, Jilid VI, Direktorat Jenderal Pengawasan Obat dan Makanan, Jakarta; 1995.

14. Robinson, T. Kandungan Organik Tumbuhan Tingkat Tinggi, Penerbit ITB, Bandung 1995; 152-196.

15. Chun, O.K., Kim D.O., and Lee C.Y. Superoxide Radical Scavenging Activity of The Mayor Polyphenols in Fresh Plums, Journal of Agricultural and Food Chemistry 2003; 51: 8067-8072

16. Depkes RI. Farmakope Herbal Indonesia, Edisi I, Departemen Kesehatan Republik Indonesia, Jakarta, Indonesia 2008

17. Malik, A., dan Ahmad, A. R. Determination of Phenolic and Flavonoid Contents Of Ethanolic Extract Of Kanunang Leaves (Cordia myxa L.), International Journal of PharmTech Research 2015; 7(2): 243-246 
18. Chang C. Yang M, and Wen H. C. J., Estimation of Total Flavonoid Content in Propolis by Two Complementary Colorimetric Methods, J. Food Drug Anal 2002

19. Ditjen POM. Parameter Standar Umum Ekstrak Tumbuhan Obat, Cetakan Pertama, Departemen Kesehatan Republik Indonesia, Jakarta; 2000.

20. Depkes RI. Parameter Standar Umum Ekstrak Tumbuhan Obat, Direktorat Jenderal Pengawasan Obat dan Makanan, Jakarta; 2000.

21. Sulistyo, S. Pengaruh Jenis Dan Konsentrasi Pelarut Terhadap Rendeman Ekstrak Flavonoid Daun Sawo Duren (Crysophillum cainito L.) Dengan Metode Maserasi, Publikasi Ilmiah, Program Studi Teknik Kimia Fakultas Teknik Universitas Muhammadiyah Surakarta, Surakarta; 2019.

22. Anungputri, P. S. Kajian Pembuatan Gmbir Bubuk Dari Daun Gambir (Uncaria gambir Roxb.) Kering Menggunakan Spray Dryer, Skripsi, Fakultas Teknologi Pertanian Institut Teknologi Bogor, Bogor; 2010.

23. Purwati, S., Sonja V. L., dan Samsurianto, Skrining Fitokimia Daun Saliara (Lantana camara L) Sebagai Pestisida Nabati Penekan Hama Dan Insidensi Penyakit Pada Tanaman Holtikultura Di Kalimantan Timur, Prosiding Seminar Nasional Kimia, Universitas Mulawarman, Kalimantan Timur; 2017.

24. Widyawati, P. S., Wijaya, H., Harjosworo, P. S., Sajuthi, D. Aktivitas Antioksidan Berbagai Fraksi dan Ekstrak Metanolik Daun Belutas (Pluchea indica Less), Agritech 2012; 32(2):249-257.

25. Azizah, D. N., Kumolowati, E., dan Faramayuda, F. Penetapan Kadar Flavonoid Metode $\mathrm{AlCl}_{3}$ Pada Ekstrak Metanol Kulit Buah Kakao (Theobroma cacao L.), Kartika Jurnal Ilmiah Farmasi 2014; 2(2): 45-49.
26. Salim, E., Afritunando, Y., Febriana, E. A., Efdi, M. Studi Optimasi Ekstraksi Kandungan Senyawa Fenolik Total Dan Uji Aktivitas Antioksidan Dari Daun Manggis (Garcinia mangostana Linn.), Jurnal Riset Kimia 2019;10(1):36-43. 